\title{
ARI JOLKKONEN
}

\section{Mikä oikeuttaa yliopistojen täydennyskoulutuksen?}

Sivistysyliopiston tarinassa sivistyksestä puhuttaessa on käytetty mm. metaforia temppeli, jano, liesi, suoja, valo, lamppu, liekki, puu, viljeleminen, pelto, kukkaan puhkeaminen. Tämä yliopistorituaalien ylevä kieli on vaikeasti siirrettävissä täydennyskoulutuskeskusten ilmaisuihin. Niiden yhteydessä sivistyksestä on tullut pikemminkin sivistystehtầä.

Sivistystehtäväänsä hoitavien täydennyskoulutuskeskusten kurssikaruselli pyörii kuitenkin sen varassa, että tiede on karusellin tukevana keskipisteenä. Tíedelaitosten näkökulmasta markkinoita etsittäessä kurssikarusellin rata on kasvanut niin laajaksi, että se vaarantaa koko korkeakoulun tieteellistä statusta.

Kysymys, kuinka täydennyskoulutuskeskukset ovat löytäneet ja säilyttäneet paikkansa yliopistoissa, kaipaa aidosti vastausta. Tämä on myös täydennyskoulutuskeskusten ongelma. Kuinka ne voivat perustella oman olemassaolonsa perinteiden määrittämässä yliopistossa ja samalla toimia yliopiston perinteiden vastaisesti?

Etsin vastausta tähän kysymykseen tarkastelemalla täydennyskoulutuskeskusten itseymmärrystä. Pyrkimyksenä on selvittää, miten täydennyskoulutuskeskusten tuomat uudet toiminnot ja toimintatavat jäsentyvät toimijoiden tietoisuudessa.
Miten toimijat sovittavat täydennyskoulutuksen yliopistoon ja millaiseen yliopistoon?

\section{Täydennyskoulutuksen \\ kaksinainen asema - kadehdittu käenpoika}

Täydennyskoulutuskeskus määrittelee itseään ensiksikin suhteessa yliopistoon ja sen perinteeseen, toiseksi suhteessa ympäröivän yhteiskunnan tarpeisiin ja erilaisiin yhteiskunnallisiin jakoihin ja kolmanneksi suhteessa muihin täydennyskoulutusta ja tutkimuspalveluja tarjoaviin laitoksiin. Kaikki nämä suhteet ovat jännitteisiä. Täydennyskoulutuskeskus määrittelee itseään juuri näiden jännitteiden kautta.

Korkeakoulun sisällä täydennyskoulutuskeskus on toisaalta "ei-vielä" asemassa, mutta toisaalta se on jo kateuden kohteena. Täydennyskoulutuskeskuksissa työskentelevät uskovat tekevänsä tärkeää työtä, jonka arvoa korkeakoululaitos "ei vielä" ole ymmärtänyt. (viite 1 sivulla 226). Täydennyskoulutuskeskuksien "ei vielä-asema" koskee myös niiden toiminnan luonnetta. Keskuksissa tiedostetaan, että muun korkeakoulunväen on vaikea pitää keskusten toimintaa osana korkeakoululaitosta, koska keskukset toimivat eri tavalla.

Vaikka täydennyskoulutuskeskukset tavoittelevat korkeakoulujen sisällä tasavertaista asemaa tiedelaitosten kanssa, niissä työskentelevät uskovat toisaalta olevansa jossakin suhteessa tiedelaitoksia paremmassa asemassa. Tämä parempi asema synnyttää muilla laitoksilla kateutta ja penseää suhtautumista täydennyskoulutuksen kehittämiseen. Muilla laitoksilla työskentelevät näyttävät ainakin Turun yliopistossa todella kadehtivan käenpoikana paisuvaa täydennyskoulutuskeskusta (Järvi ym. 1990). Täydennyskoulutuskeskukset edustavat it- 
seymmärryksensä mukaan varakkuuden lisäksi nuoruutta, vireyttä, dynaamisuutta ja vapautta. Dynaamisuus ja vireys tarkoittaa sitä, että täydennyskoulutuskeskus yrittää mahdollisimman nopeasti reagoida erilaisiin koulutustarpeisiin. Kateutta synnyttävä uuden ja vanhan jännite antaa täydennyskoulutuskeskuksille aseman, josta ne voivat tarkastella muuta korkeakoulua ylemmyyden perspektiivistä.

Täydennyskoulutuskeskusten perusongelma on kuitenkin se, että niiden toiminta ei tunnu saavuttavan itsestäänselvää, hyväksyttyä ja arvostettua asemaa perusopetuksen ja tutkimuksen rinnalla. Tämä arvostuksen puute on samanlaista kuin akateemisten alojen keskinäisessä kilpailussa heikommin menestyvillä. Suhteessa täydennyskoulutukseen muu korkeakoulu kuitenkin näyttäytyy yhtenäisenä. Täydennyskoulutuskeskus tuntee kilpailevansa tieteellisten yksikköjen kanssa paitsi arvostuksesta niin myös oikeudesta kontrolloida ja päättää opetuksesta. Avoimia konflikteja on syntynyt erityisesti silloin, kun täydennyskoulutuskeskus on aloittanut sellaista tutkintoon tähtäävää tai pätevyyden antavaa opetusta, jonka aloittamista korkeakoulun tämän alan perusopetuksesta vastaava yksikkö on vastustanut.

\section{Hallittu harppaus täydennyskoulutettuun tietoyhteiskuntaan}

Täydennyskoulutuskeskusten toimintaideologiassa korostetaan voimakkaasti sekä yhteyttä korkeakouluun ja tieteeseen että ympäristön käytännöllisiin ongelmiin. Keskukset perustelevat tarpeellisuuttaan juuri sillä, että ne muodostavat maaperän teorian ja käytännön kohtaamiselle.

Idea täydennyskoulutuskeskusten tehtävästä teorian ja käytännön välittäjänä on niiden olemassaolon oikeutuksen kulmakysymyksiä. Tätä käsitystä eivät jaa ainoastaan täydennyskoulutuskeskuksissa työskentelevät, vaan usein koulutuspolitiikasta vastaavat ja tutkijat arvioivat tilanteen samalla tavalla. "Tieteen ja käytännön, yliopiston ja työelämän välisten ongelmien ratkaisemiseen korkeakoulujen ammatillinen täydennyskoulutus on tuonut uuden ja suositun instrumentin. Täydennyskoulutuksen ekspansio on Suomessa tästä ilmeinen esimerkki. Tällä hetkellä se koetaan ainakin julkisessa keskustelussa suhteellisen toimivalta vastaukselta ongelmaan." (Panhelainen 1991, 6). Täydennyskoulutuskeskusten todellisin markkinarako on tieteen ja käytännön välissä.
Kun täydennyskoulutuskeskuksissa työskentelevät tai tutkijat arvioivat tieteen ja käytännön, yliopiston ja ympäristön tai koulutuksen ja ammatin suhteita vastaavien dikotomioiden avulla, erotteluja ei pidetä pelkästään analyyttisina, vaan yliopisto ja ympäristö (ks. viite 2 sivulla 226 ) mielletään toisistaan poikkeaviksi maailmoiksi. Kun näiden erilaisten maailmojen suhdetta arvioidaan yliopisto-ympäristö erottelun lähtökohdista, tarkastelija sijoittaa itsensä ei-ympäristöön. Yliopisto on tässä asetelmassa kiintopiste, josta eri maailmojen suhdetta arvioidaan. Täydennyskoulutuskeskuksen ajatellaan lähentävän näitä maailmoja luomalla tilanteita, joissa niiden "kontaktipinta" laajenee.

Täydennyskoulutuskeskus ei ainoastaan muodosta puitteita erillisten maailmojen kohtaamiselle, vaan samalla se sääntelee kohtaamista, mikä perustelee toiminnan sekä määrällistä että sisällöllistä laajentamista. Kun täydennyskoulutuskeskus laajenee, niin yliopiston kontaktipinta ympäristöön laajenee riippumatta toiminnan sisällöstä. Täydennyskoulutuskeskus varjelee tieteen maailman puhtautta suodattamalla yliopiston toimintaan sopimattomat vaikutteet ja estämällä niiden leviämisen. Tässä yliopisto mielletään Kerrin (1964) tapaan multiversityksi. Multiversityksi ymmärretty yliopisto voi samanaikaisesti erään haastateltavan sanoin "toiselta laidaltaan tehdä koulutuksellisen tasa-arvoisuuden työtä ja toiselta laidalta se voi ottaa rahaa sieltä mistä rahaa saa".

Aittolan (1988) mielestä Kerrin (1964) esittämä käsitepari "university" -"multiversity" ei nykyisessä tilanteessa enää tarjoa riittävää vastausta kysymykseen, kuinka yliopisto voi säilyä yliopistona omaksuessaan ristiriitaisia tehtäviä yhteiskunnallisten tarpeiden tyydyttäjänä, koska yliopisto on menettänyt johtavan intellektuaalisen instituution aseman jälkiteollisessa teknisen tiedon hallitsemassa maailmassa.

Aittola tulkitsee täydennyskoulutuskeskusten toteuttamia uusia tehtäviä samoin kuin hallinnollista tuloksellisuuden laskemista weberiläisestä rationalisoitumisen perspektiivistä. Uudet tehtävät edustavat yliopistolle ja tieteelliselle kulttuurille vieraita ilmiöitä. Aittola pelkää, että tässä erilaisten kulttuurien ja rationaalisuuden muotojen törmäyksessä yliopistoon ja tieteeseen kiinnittyneet kulttuurin ja rationaalisuuden muodot saavat nykyisissä oloissa enemmän säröjä kuin yliopistoon ulkopuolelta tunkeutuvat kulttuurin ja rationaalisuuden muodot. 
Yliopiston ja ympäristön, tieteen ja käytännön periaatteellinen erilaisuus on siis sekä täydennyskoulutuskeskuksien kehittämisen että täydennyskoulutuskeskuksiin kielteisen suhtautumisen lähtökohta. Ilman tätä erilaisuutta täydennyskoulutuskeskukset eivät voisi esiintyä tarpeellisina välittäjinä eikä toisaalta niitä voisi pitää yliopistoon sopimattomina. Maailmasta erillinen "pyhä ja oikea yliopisto" (Koski 1990a) on siis vaikuttavana läsnä.

\section{Yliopisto, kenttä, maakunta ja yliopistotietämys}

Mikä erottaa yliopiston ympäristöstä tai maakunnan kenttäväestä? Yliopisto erotetaan ei-yliopistosta yliopistotietämyksen perusteella. Yliopistolla on hallussaan uusinta uutta, kansainvälistä, tieteellistä yliopistotietämystä. Tämä tieteellinen huipputietämys on tuotettu tieteen kehittymisen intresseistä lähtien. Jokainen yliopisto on periaatteessa osallinen kaikesta maailman tieteellisestä tiedosta. Tämä tieto on yhteiskunnalle arvokasta, mutta yliopistoissa se on epäkäytännöllisen tiedeyhteisön hallussa.

Perusopetus tai jatkokoulutus eivät murra epäkäytännöllisyyden piiriä eivätkä toisaalta tuota sellaisia akateemisia, jotka itsenäisesti pystyisivät omassa ammatissaan pysyttelemään uusimman tietämyksen tasolla, mikä on perinteinen ihanne ja monien koulutusohjelmien julkilausuttu tavoite. Tämän vuoksi yliopistotietämyksen siirtäminen epäkäytännöllisestä yliopistosta ympäristön, kentän tai maakunnan käytäntöihin edellyttää instrumentaalisempia muotoja, joita täydennyskoulutuskeskukset ovat kehittäneet. Täydennyskoulutuskeskuksille on tärkeää korostaa yhteyttä yliopistotietämykseen. Yhteys yliopistotietämykseen säilytetään järjestämällä korkeakoulutasoista täydennyskoulutusta.

\section{Yliopisto ja markkinat}

Korkeakoulutasoisuus on markkinoiden termi. Yliopistotietämyksestä kertovan korkeakoulutasoisuuden erityinen merkitys on, että korkeakoulutasoisuus toimii markkinoiden sulkemisstrategian keskeisenä perusteluna. Juuri toimintansa väitetyn korkeakoulutasoisuuden avulla korkeakoulujen täydennyskoulutusyksiköt voivat erottautua muista vastaavista koulutuksen tarjoajista (ks. Parjanen 1985).
Kun yliopiston ja ympäristön suhde nähdään markkinametaforan valossa yrityksen ja asiakkaan suhteena, yliopisto nähdään silloin koulutuksen tuotantolaitoksena ja markkinat koulutuksen markkinoina. Koulutuksen alalla markkinametafora ammentaa osan voimastaan koulutustutkimuksen teoriasta.

Turun yliopiston koulutussosiologian tutkimusyksikön tutkimuksissa (ks. esimerkiksi Kivinen \& Rinne 1990) on käytetty koulutusmarkkinat-käsitettä välineenä, jonka avulla on etsitty koulutuslaitosten paikkaa koulutuksen kentällä. Koulutusmarkkinoilla myydään ja ostetaan koulutusta. Kun täydennyskoulutuksessa työskentelevät puhuvat yliopiston ympäristöstä markkinoina, he käyttävät käsitettä koulutusmarkkinoiden merkityksessä. Markkinoilla toimimisesta täydennyskoulutuskeskukset saavat dynaamisen luonteen. Täydennyskoulutuskeskusten hyveenä esitetään niiden mahdollisuus reagoida nopeasti kysyntänä ilmeneviin tarpeisiin (vrt. Parjanen 1985,195). Hyvän täydennyskoulutussuunnittelijan pitäisi aavistaa tarpeet jo ennen niiden ilmenemistä.

Markkinoiden edellyttämä dynaamisuus törmää yliopistoissa kahteen esteeseen: hallintoon ja tiedeyhteisön ideologiaan. Hallinto "tsaarinaikaisine byrokratioineen" ja säännöksineen estää tai ainakin merkittävästi vaikeuttaa dynaamista toimintaa. Törmäys tiedeyhteisön ihanteisiin on ideologinen.

Täydennyskoulutuskeskusten itseymmärryksessä Mertonin esittämiä tieteen eetokselle tunnusomaisia piirteitä (universalismi, puolueettomuus, kommunismi ja järjestelmällinen epäily) pidetään tieteen käytäntöjä kuvaavina faktoina. Merton esitti nuo neljä periaatetta tiedeyhteisölle tunnusomaisena normistona, jonka perusteella tiedeyhteisö erottautuu muusta maailmasta. Tämä esimerkiksi Bourdieun perspektiivistä naiivi käsitys tieteellisen toiminnan arkipäivästä on yhteydessä tieteen ja käytännön vastakkainasetteluun, jota ilman täydennyskoulutuskeskuksien oikeutus olisi heikommalla pohjalla. Paikallinen yliopisto edustaa tässä käsityksessä universaalia yhteisesti jaettua tieteellistä tietämystä, joka on saavutettu vain tieteen kehityksen intresseistä lähtevän ponnistelun palkkiona ja jonka totuudellisuus on koeteltu julkisessa kritiikissä. Periaatteessa tieteellinen tieto on yhteistä ja julkista.

Julkilausumaton perusoletus on se, että tiede (ts. yhteiskunnan ylläpitämät tiedelaitokset) on olemassa käytäntöä varten ja siksi näitä erilaisia 
käytäntöjä voidaan pyrkiä lähentämään. Ahdaskatseiset, paikallisesti rajoittuneet, yksityisintresseihin ja perinteisiin sitoutuneet maakunnan miehet eivät pysty ylittämään omin voimin tieteen ja käytännön kuilua. Tiedemiehet puolestaan eivät näe tarpeelliseksi kuilun ylittämistä.

Kun ympäristöä tarkastellaan markkinoina, sitä vastaan asetetaan silloin yliopisto pelkästään tieteellistä tietoa tuottavana, säilyttävänä ja siirtävänä laitoksena. Tässä asetelmassa ei ole sijaa sivistyksen teemalle. Sivistysyliopiston tarinassa sivistyksestä puhuttaessa käytetään mm. seuraavia metaforia: temppeli, jano, liesi, suoja, valo, lamppu, liekki, puu, viljeleminen, pelto, kukkaan puhkeaminen (Koski 1990b, 69). Tämä yliopistorituaalien ylevä mutta luonnollinen kieli tuntuu vaikeasti siirrettävältä täydennyskoulutuskeskusten ilmaisuihin. Täydennyskoulutuksen yhteydessä sivistyksestä puhuttaessa ei käytetä metaforia, vaan sivistyksestäkin on tullut sivistystehtävä.

Täydennyskoulutuksen näkökulmasta yliopisto näyttäytyy sivistyslaitoksena vain suhteessa maakunnaksi ymmärrettyyn ympäristöön. Kurssitoiminnan markkinallistumista ei vastusteta sivistyksen perinteestä lähtien, vaan tietyn tyyppisiä kursseja pidetään yliopistoille kuulumattomina siksi, että ne eivät täytä tieteelliseen tietoon viittaavan korkeakoulutasoisuuden kriteereitä ja epäkelpoina tuotteina varantavat markkina-aseman.

Täydennyskoulutuskeskuksille professionalismi-ideologia, ja sen kanssa yhdensuuntainen funktionalistinen professioteoria, on läheistä siksi, että professionaalinen toiminta usein käsitetään asiakkaan "arkitoiminnan" tieteellisessä mielessä loogiseksi saattamisena. Tieteellinen asiantuntemus antaa professionaaleille kyvyn toimia tulkkina eri kieltä puhuvan jokapäiväisen elämän ja tieteen välillä (Konttinen 1989).

Pitkän, teknisen kompetenssin takaavan, tieteellisen koulutuksen lisäksi professionaalisille ryhmille on funktionalististen käsitysten mukaan tunnusomaista palveluideaalia ja yhteisöllistä asennoitumista korostava eettinen koodi. Tähän eettiseen koodiin sisältyy varsinkin eurooppalaisissa tulkinnoissa voitontavoittelun ja liike-elämän vastaisuus (Konttinen 1989). Korkeakoulujen toiminnan professionalismiin kiinnittyvää ideologista taustaa kuvaa jo se, että kurssien myyntiä kutsutaan maksulliseksi palvelutoiminnaksi. Kysymys markkinoista konkretisoituu juuri kurssien maksullisuutta koskevana kysymyksenä.
Täydennyskoulutuskeskukset joutuvat puolustamaan sitä, että ne myyvät yliopistotietämystä, vaikka esitetty yliopiston luonne ja tiedemiesten professionaaliset perinteet velvoittaisivat välittämään sitä ilmaiseksi. Perusteluksi jää se, että koulutuksen myyminen tuo rahaa yliopistolle. Jos yliopisto ei palvele myymällä koulutusta, kurssin järjestää joku muu. Panhelainen (1991, 6) arvioi, että täydennyskoulutuksen legitimointiprosessissa sen aseman vahvistuminen viime vuosina on perustunut pääosin yliopiston saamaan taloudelliseen hyötyyn, jolla on rahoitettu muuta toimintaa.

Täydennyskoulutuskeskuksissa toimiville markkinallisuuden ja korkeakoulutasoisuuden ristiriita ilmenee asetelmana "bisnestä vai pitkiä kursseja". Täydennyskoulutuskeskusten yhteinen linja on siirtyminen lyhytkursseista pitkäaikaisempaan koulutukseen. Voimakas halu sanoutua irti "kurssikarusellin pyörittämisestä" heijastaa täydennyskoulutuskeskusten pyrkimystä erottautua muista täydennyskoulutuksen tarjoajista korkeakoulutasoisuuden avulla. Lyhytkurssit ovat tuottoisampi koulutusmuoto kuin pitkäaikainen koulutus.

Täydennyskoulutuskeskusten markkinarako on ahdas. Niiden on vaikea löytää sellaisia asiakkaita, jotka maksaisivat korkeakoulun tieteellisten laitosten tieteellisenä pitämästä koulutuksesta. Parjasen $(1985,1991)$ mukaan keskeistä on se, että organisatorinen yhteys korkeakouluun tarjoaa täydennyskoulutukselle sen tarvitseman tieteellisyyden leiman. Näin leimattu koulutus sopii monille asiakkaille vähintään yhtä hyvin kuin tieteellinen koulutus. Täydennyskoulutuskeskusten kurssikaruselli pyörii kuitenkin sen varassa, että tiede on karusellin tukevana keskipisteenä. Tiedelaitosten näkökulmasta markkinoita etsittäessä kurssikarusellin rata on kasvanut niin laajaksi, että se vaarantaa koko korkeakoulun tieteellistä statusta (ks. Järvi ym. 1990)

Täydennyskoulutuskeskus joutuu arvioimaan ja puolustamaan toimintalinjaansa paitsi suhteessa asiakkaisiinsa, myös tieteen edustajiin. Asiakkaiden palaute on markkinapalautetta. Tieteen edustajilta täydennyskoulutuskeskukset joutuvat hankkimaan hyväksyntää ja arvostusta. Täydennyskoulutuskeskukset pyrkivät toisaalta määrittelemään oikeutetuimmiksi tieteen edustajiksi ne, jotka ovat kyllin hyviä täydennyskouluttajiksi. (ks. viite 3, sivu 226) Tieteen marginaalia edustava "nuorin assistenttipolvi" tai "epätoivoprofessorit" eivät pärjää täydennyskoulutuksessa. Tieteen edustajien taholta tulevan kritiikin merkitystä vähentää siis se, 
että tämän kritiikin taakse voidaan asettaa lähinnä ne, joiden hyväksyntäkään ei olisi arvokasta.

Täydennyskoulutuskurssin suurin häpeä on kuitenkin sen korkeakoulutasoisuuden epääminen. Kurssille olisi hyväksi, että suuri osa opettajakunnasta löytyisi omasta korkeakoulusta kelvollisen väen piiristä, koska muutoin on vaikea perustella täydennyskoulutuskeskuksen välitystehtävää, korkeakoulun ja ympäristön kontaktipinnan laajenemista ja kurssin tieteellisyyttä.

Tärkeää on lisäksi, että kurssilla esiintyy riittävän nimekkäitä asiantuntijoita. Tässä suhteessa korkeakoulujen täydennyskoulutukset kokevat ongelmaksi yhteyden korkeakouluun, joka sitoo niiden käsiä opetuspalkkioiden suhteen. "Kukaan itseään kunnioittava koulutusasiantuntija ei näillä palkoilla lähde panemaan kykyjään peliin."

\section{Tiede ja tietoyhteiskunnan käytännöt}

Yliopiston ja ympäristön jännitteiden polttopisteessä on tieteen ja käytännön suhde. Mikä on se käytäntö, johon yhteyttä rakennetaan? Tätä käytäntöä kutsutaan talouselämäksi tai yritysmaailmaksi, mutta yritys- ja talouselämä nähdään yksipuolisesti tuottamisen näkökulmasta. Tieteen ja käytännön jännite ei ole tieteen ja markkinoiden ohjaamien yritysten intressien vastakohtaisuutta vaan tieteen tarjoamien potentiaalien ja näitä potentiaaleja puutteellisesti hyödyntävän tuotannon ristiriitaa.

Tällaisesta tieteen ja käytännön ristiriidan tulkinnasta täydennyskoulutuskeskuksille avautuu valoisa visio, johon muutkin kuin täydennyskoulutuskeskuksissa toimivat ovat sitoutuneet. 1980luvun suomalaisessa yhteiskunnassa oli kaksi merkittävää politiikkaohjelmaa, joissa nämä ajatukset muotoiltiin: (1) hallittu rakennemuutos teollisesta yhteiskunnasta jälkiteolliseen tietoyhteiskuntaa ja tämän politiikan käytännöllisenä sovellutuksena (2) innovaatio-orientoitunut aluepolitiikka. Nämä päällekkäiset politiikkaohjelmat määrittävät täydennyskoulutuskeskuksissakin toimivien puhetta korkeakoulun yhteiskunnallisista tehtävistä ja niiden tulevaisuudesta.

Kivinen ja Rinne $(1990,14)$ katsovat, että "aluepoliittinen kytkös on ehkä keskeisin koko (täydennyskoulutuskeskusten) toiminnan muotoutumista selittävä tekijä". Aluepoliittinen kytkös on osa laajemmasta hallitun rakennemuutoksen ja tie- toyhteiskunnan kehyksestä, jonka puitteissa korkeakoululaitoksen yhteiskunnallinen oikeuttaminen edellyttää yliopiston hyödyllisyyttä määrätylle yhteiskunnan kehityssuunnalle.

"Tietoyhteiskunnan käänne" näkyy selvästi aluepolitiikassa. Uuden innovaatio-orientoituneen aluepolitiikan lähtökohdista korkeakoulua arvioidaan potentiaalisena alueellisena kehittämiskeskuksena muiden potentiaalisten kehittämiskeskusten rinnalla. Täydennyskoulutuskeskusten toimintamuodot ja niiden ympäristössä synnyttämä vastakaiku ovat osittain ymmärrettävissä tämän aluepoliittisen käänteen näkökulmasta.

Tuolloin tiedettiin, että tulevaisuus on tiedossa. Vision toteuttamiseen tarvittiin tiettyjä instrumentteja: "Myös Suomessa aluepolitiikan suuri haaste 1980- ja 1990-luvuilla on tietoyhteiskunnan vaatimuksia vastaavan uuden perusrakenteen luominen. Mitä tämä voisi olla käytännössä: eri tasoisten ( eri yhdyskuntatyyppeihin soveltuvien) tietokasvunkeskusten kehittymisen kannustamista. Tietokasvunkeskuksissa syntyisi edellytykset luoville yhteisöille. Rakennusosia olisivat yliopistot ja korkeakoulut, niihin liittyvät tutkimuslaitokset ja koulutuskeskukset, keski- ja perusasteen ammatilliset oppilaitokset, VTT:n hajautetut yksiköt jne. Yhteistyön osapuolia olisivat myös rahoitusorganisaatiot, hallinto- ja kulttuurielämä. Näissä toimivat ihmiset saatettaisiin synergiaa luovaan yhteistyöhön yritysten kanssa." (Paasivirta 1985). Aluepolitiikkatoimikunnan mietinnössä (Komiteanmietintö 1986:6) tämä "piilaakso-politiikka" tuli koko maata koskevan aluepolitiikan lähtökohdaksi ja alueen taitotietotason kohottaminen päällimmäiseksi asiaksi.

Korkeakoulujen uusia tehtäviä koskevassa virallisessa keskustelussa on tapahtunut samanlainen nopea muutos kuin aluepolitiikassa. 1980-luvun alussa nämä uudet tehtävät olivat ulkopuolisessa suhteessa "perinteellisiin perustehtäviin" vaikkakin ne yhteiskunnan muutoksen vuoksi olivat tulossa osaksi perustehtäviä (Linna 1983). Tällainen käsitys uusien ja perinteellisten tehtävien erosta oli ajanmukainen 1980-luvun alkupuolella. 1980luvun lopulta lähtien se on saman arvioijan mukaan auttamattoman vanhanaikainen (Linna 1987).

Korkeakoululaitokseksi muuttuneella yliopistolla ei enää näytä olevan "perinteellisiä" ja "uusia" tehtäviä, vaan kaikesta toiminnasta on tullut korkeakoulun "varsinaista toimintaa". Tällainen tulkinta korkeakoulujen tehtävästä osoittaa uusien 
toimintamuotojen integroitumista ja legitimoitumista informaatioyhteiskunnan tehokkuuden yliopistoon. Myös korkeakoulujen suunnittelukäytännöissä uudet opetuksen, tutkimuksen ja kehittämistoiminnan muodot ovat saaneet aseman perinteisten muotojen rinnalla. Suunnittelu- ja hallintokäytännöissä puhe vanhoista ja uusista tehtävistä on tullut vanhanaikaiseksi.

Kun täydennyskoulutuskeskukset rakentavat siltaa tuotantotoiminnaksi ymmärretyn käytännön ja yliopistojen tieteen välille, niin tässä asetelmassa tieteen paikkaa ei voi ottaa tiede yleensä. Tuotantoprosessin vastinpariksi käyvän tieteen on tässä asetelmassa oltava potentiaalinen tuotantoprosessi, mahdollinen tuleva tekniikka. Tieteen ja käytännön lähentäminen on tuotannon tieteellistämistä, innovaatio-potentiaalin kohottamista, tietoyhteiskunnan rakentamista. Niin kaukana kuin tällainen ajatus onkin täydennyskoulutuskeskusten toimintakäytännöstä, niin se on kuitenkin sen käytännön perustelu.

\section{VIITTEET}

1. Arviot täydennyskoulutuskeskuksia edustavien inmisten käsityksistä perustuvat yhdessä Kari Kantasalmen kanssa tekemääni suunnittelutehtävissä toimiville osoitettuun kyselyyn (1988) ja Kantasalmen tekemisiin johtotehtävissä toimivien haastatteluihin (1989).

2. Yliopisto - ympäristö -metaforan rinnalla käytetään metaforia yliopisto - kenttä ja yliopisto - maakunta. Kentän käsitettä käytetään korostamaan johtavassa asemassa olevien näköalojen ja käsitysten erillisyyttä kenttäväkeen nähden. Yliopiston ulkopuolella toimivat akateemiset ryhmät eivät kuulu näin ymmärrettyyn kenttään, vaan ne nimitetään yleensä ammattikunnan mukaan. Yliopiston pitää päättäväisesti kieltäytyä omaksumasta kentän käytäntöihin sitoutunutta näkökulmaa, mutta sen pitää kuitenkin pyrkiä lähentymään kenttää. Yliopistolle on siis tärkeää yhdellä korvalla kuunnella kentän ääntä ja samalla pysyä sille kuurona.

Yliopiston ulkopuolinen maailma ei ole pelkästään historiaton ja perinteisiin sitoutumaton ympäristön tai kentän hahmoinen objekti, vaan välillä myös maakunnan hahmon saava innokas toivoja ja odottaja.

3. Vastaavasti tiedelaitosten edustajat arvostelevat täydennyskoulutuskeskuksien työntekijöitä tieteellisen asiantuntemuksen ja kokemuksen puutteesta (Järvi ym. 1990, 46-47).

\section{LÄHTEET}

Aittola, T. 1988. The Case of university. Teoksessa Aittola, T. \& Eräsaari, R. Rationalization on the university and the social science. Jyväskylän yliopiston yhteiskuntapolitiikan laitoksen työpapereita. N:o 53, 1-13.

Järvi, P., Kivinen, O. \& Rinne, R. 1990. Yliopiston tila ja tahto. Turun yliopisto. Koulutussosiologian tutkimusyksikön tutkimusraportteja 5.

Kerr, C. 1964. The uses of the university. Cambridge.

Kivinen, O \& Rinne, R. 1990. Korkeakoulujen täydennyskoulutuksen muuttuva asema osana uutta aikuiskoulutusstrategiaa. Teoksessa Kivinen, O. \& Rinne, R. Korkeakoulut aikuiskoulutusmarkkinoilla. Turun yliopisto. Koulutussosiologian tutkimusyksikön tutkimusraportteja 4, 11-16.

Komiteanmietintö 1986. Aluepolitiikkatoimikunnan mietintö. Komiteanmietintö 1986, 6.

Konttinen, E. 1989. Harmonian takuumiehiä vai etuoikeuksien monopolisteja?: professioiden sosiologian funktionalistisen ja uusweberiläisen valtasuuntauksen tarkastelua. Jyväskylän yliopisto, sosiologian laitoksen julkaisuja; 45.

Kortteinen, M. 1987. Hallittu rakennemuutos? Hanki ja jää.

Koski, L. 1990a. Pyhä ja oikea yliopisto. Tiede \& edistys. 4/90: 249-259.

Koski, L. 1990b. Tarinoiden yliopisto tehokkuuden diskurssissa. Joensuun yliopisto, Kasvatustieteiden tiedekunnan tutkimuksia n:o 28.

Linna, M. Korkeakoulujen täydennyskoulutus - sillisalaattiako? Korkeakoulutieto 7/1983, 3.

Linna, M. Täydennyskoulutus osana korkeakoulujen toimintaa. Korkeakoulutieto 4/1987, 3.

Paasivirta, A. 1985, Alueellisen kehityksen uhkat ja mahdollisuudet, Teoksessa Alasentie, J., Salonen, I. (toim.) Aluepolitiikan uudet haasteet. Aluesuunnittelupäivien 1984 seminaariraportti. Tampereen yliopisto, Aluetiede, Tiedonantoja n:o 22. Tampere 1985 ss. 8-16.

Panhelainen, M. 1991. Korkeakoulujen täydennyskoulutus työorganisaatioiden ja professioiden muutoksessa. Teoksessa Parjanen, M. (toim.) Privaatti vai piraatti. Tampereen yliopiston täydennyskoulutuskeskus. Julkaisusarja a $1 / 91,1-18$

Parjanen, M. 1985. Extension studies under pressure from work life, training and myths. Teoksessa Mäkinen, R. ym. (toim.) Recent Finnish research on higher education. Kasvatustieteiden tutkimuslaitoksen julkaisuja 364/1985, 191-212

Parjanen, M. 1991. Legitimaatio ja diplomitauti korkea-asteen aikuiskoulutuksessa. Teoksessa Parjanen, M. (toim.) Privaatti vai piraatti. Tampereen yliopiston täydennyskoulutuskeskus. Julkaisusarja a 1/91, 17-38. 